\title{
INFLUENCE OF MOZZARELLA AND SEMI-RIPENED CHEDDAR CHEESE AMALGAMATIONS ON THE CHEMICAL COMPOSITION AND TEXTURAL ATTRIBUTES OF PROCESSED PIZZA CHEESE
}

\author{
Nabila Gulzar ${ }^{1, *}$, Aysha Sameen ${ }^{1, *}$, Nuzhat Huma ${ }^{1}$ and Muhammad Shahid ${ }^{2}$ \\ ${ }^{1}$ National Institute of Food Science and Technology, University of Agriculture, Faisalabad, Pakistan; \\ ${ }^{2}$ Department of Chemistry and Biochemistry, University of Agriculture, Faisalabad, Pakistan. \\ "Corresponding author's e-mail: nabila.hussain986@gmail.com
}

\begin{abstract}
Processed pizza cheeses (PPC) are the mixture of Mozzarella and other cheeses which is pasteurized with the addition of emulsifier to get the desired characteristics of cheese, used as pizza topping. Mostly being used cheese on pizza topping is fresh Mozzarella but it has some week quality attributes due to lack of biochemical reactions that takes place during ripening. Present study was designed in which PPC was prepared by blending different percentages of Mozzarella cheese (MC) and semi-ripened Cheddar cheese (SRCC). Seven PPC were prepared: Control (100\% MC), $\mathrm{PPC}_{1}, \mathrm{PPC}_{2}, \mathrm{PPC}_{3}$ with (75:50), (50:50), (25:75) $\mathrm{MC}$ and 2 months SRCC and $\mathrm{PPC}_{4}, \mathrm{PPC}_{5} \mathrm{PPC}_{6}$ with (75:50), (50:50), (25:75) MC and 4 months SRCC respectively. The quality of PPC was accessed by analyzing the chemical composition and textural attributes. The outcome of chemical composition suggested that protein-protein interactions in PPC were improved due to less electrostatic repulsion caused by $\mathrm{pH}$ reduction. Moisture retention also increased in PPC perhaps due to disintegration of paracaseinate complex and mechanical shear and temperature of processing. Protein, fat and ash contents of PPC were increased while texture results indicated that hardness, cohesiveness, springiness, gumminess and chewiness decreased in PPC with greater share of SRCC. Based on the physicochemical and texture results it was concluded that cheese with better quality can be obtained by blending $75 \% \mathrm{MC}$ and $25 \%$ two months SRCC.

Keywords: Composition, texture, pizza cheese, casein chains, semi-ripened cheese.
\end{abstract}

\section{INTRODUCTION}

Chemistry and biochemistry of natural cheeses influence the functional properties of resultant Processed pizza cheese. These variations are due to difference of natural cheese source and age. Natural cheese differed due to fat content, moisture content (Lee et al., 2005 ), pH (Lee and Klostermeyer, 2001), total calcium content, intact casein (Garimella et al., 2006), lactose content, and whey protein content. The melt and stretch performance of cheese when baked on pizza is influenced by cheese composition, $\mathrm{pH}$ history (especially extent of acidification at coagulant addition), insoluble colloidal calcium phosphate content, and the amount of intact casein (Johnson and Lucey, 2006).

The major component of most Processed cheese manufacture in the United States is Cheddar cheese. A typical Processed cheese contains about 15 to $20 \%$ aged cheese. Young cheese is preferred for textural and performance issues, whereas aged cheese offers better flavor (Hickey et al., 2007). In addition to lack of flavor, young cheeses suffer from textural problems such as excessive firmness, rubbery texture, and decreased melting properties. The properties of Cheddar cheese used in Processed cheese making have direct impact on the quality attributes of the final product . As cheese ages, residual proteolytic activity of the coagulant can quickly hydrolyze sufficient casein to greatly increase flowability and decrease the stretch of cheese, both to the extent that bake performance may be negatively affected (Moynihan et al., 2013).

The functional properties of Processed cheese are determined by the ingredients used in the formulation (i.e., type of natural cheese, age of natural cheese, amount of natural cheese, type and amount of emulsifying salt) as well as processing conditions (i.e., cooking temperature, cooking time, and mixing speed during manufacture). The variations in the chemical properties of a Processed cheese that arise during a cheese formulation significantly influence its functional properties therefore, it is important to control the formulation parameters of Processed cheese to achieve a product with consistent functional properties (Kapoor et al., 2007). A lot of work has been done on Processed cheese prepared from Cheddar and other natural cheeses of different ages. There is no work in which Mozzarella and Cheddar cheese amalgam was used for manufacturing of Processed pizza cheese. Therefore, a study was designed to develop Processed pizza cheese by using fresh Mozzarella and semi ripened Cheddar cheese in different combinations.

The aim of the present study was to access the changes in chemical composition and texture of Processed pizza cheese developed by using Mozzarella and semi-ripened Cheddar cheese in combination. 


\section{MATERIALS AND METHODS}

Procurement of raw materials: Raw buffalo milk for the preparation of Mozzarella and Cheddar cheeses were procured from the SB Dairy Farm Jhapal, Faisalabad. 100 L of milk was used for preparation of each batch of Mozzarella and Cheddar cheese. Mixed mesophillic culture Lactococcuslactis subsp. lactis and L. lactis subsp. cremoris and thermophillic culture Streptococcus thermophillus and Lactobacillus bulgaricus (Chr. Hansen Ireland Ltd., Rohan Industrial Estate, Little Island, Co. Cork, Ireland) were used for Cheddar and Mozzarella cheese respectively. Chymosin of $50000 \mathrm{u} / \mathrm{G}$ strength of Pharm Chemical Co., Ltd. China was used as coagulant in both cheeses. Emulsifying salts disodium phosphate and trisodium citrate of Fooding Group Limited was procured from local supplier for manufacturing of Processed pizza cheeses. Three replicates of seven Processed pizza cheeses were prepared for the study.

Preparation of Processed pizza cheeses (PPC): The milk was standardized at 3\% fat level for both Mozzarella and Cheddar cheese. Cheddar cheese was prepared by following the method described by Ong et al. (2007) while Mozzarella cheese was manufactured by following the method of Zisu and Shah, (2007) with slight modification as milling was done at $4.9 \mathrm{pH}$ in order to standardize the processing steps for buffalo Mozzarella that is well suited to prepare PPC. Processed pizza cheeses were prepared by following the method of Shirashoji et al. (2006) with some variation of emulsifying salts concentration as $2 \%$ emulsifying salt was used in the study. PPC were prepared in a Blentech twin screw cooker (Blentech Corp., Rohnert Park, CA) equipped with indirect steam injection. Seven PPC were prepared: Control (100\% MC), $\mathrm{PPC}_{1}, \mathrm{PPC}_{2}, \mathrm{PPC}_{3}$ with (75:50), (50:50), (25:75) $\mathrm{MC}$ and 2 months SRCC and $\mathrm{PPC}_{4}, \mathrm{PPC}_{5}, \mathrm{PPC}_{6}$ with (75:50), (50:50), (25:75) MC and 4 months SRCC, respectively. PPC blocks of $2 \mathrm{Kg}$ weight were then repacked, vacuum-sealed and stored again at $5^{\circ} \mathrm{C}$ for further analysis.

Physicochemical analysis: Physicochemical analysis like moisture, acidity (AOAC, 1990),pH (Ong et al., 2007), protein (IDF, 1964), fat (Marshal, 1992) and total calcium (Metzger et al., 2000) of natural and PPC were determined according to standardized methods.

Texture profile analysis: Texture profile of PPC was determined by performing the texture profile analysis (TPA) on TA-XT Plus Texture Analyzer (Stable Micro Systems, Godalming, Surrey, UK) using Compression plate (Zisu and Shah, 2007).Definitions and calculated TPA parameters of the TA-XT2i texture analyzer used to measure cheese samples texture are given in Table 1.

Statistical analysis: The results were analyzed statistically by using Minitab statistical package. Complete randomized design and multiple degree of freedom contrast system were used to find out the difference between control and other treatment samples. The means were compared using Tukey's test after their significant difference (Steel et al., 1997).

Table 1. Dentitions and calculated TPA parameters.

\begin{tabular}{|c|c|}
\hline Parameters & Descriptive definition \\
\hline Hardness & Force $\mathrm{F}_{\max }$ required for $30 \%$ compression $(\mathrm{g})$ \\
\hline Length-I & Distance required to reach $\mathrm{F}_{\max }(\mathrm{mm})$ \\
\hline Area-I & $\begin{array}{l}\text { Work of first compression (integration of } \\
\text { area under first compression curve) }(\mathrm{g} / \mathrm{mm})\end{array}$ \\
\hline Length-II & $\begin{array}{l}\text { Distance from probe contact to reach } 30 \% \\
\text { compression }(\mathrm{mm})\end{array}$ \\
\hline Area-II & $\begin{array}{l}\text { Work of second compression (integration of } \\
\text { area under second compression curve) } \\
(\mathrm{g} / \mathrm{mm})\end{array}$ \\
\hline Cohesiveness & Area-II/Area-I (ratio) \\
\hline Springiness & Length-II/Length-I (ratio) \\
\hline Gumminess & Hardness x Cohesiveness (unitless) \\
\hline Chewiness & $\begin{array}{l}\text { Hardness x Cohesiveness x Springiness } \\
\text { (unitless) }\end{array}$ \\
\hline
\end{tabular}

\section{RESULTS AND DISCUSSION}

Physicochemical composition of natural cheeses: The mean of the physicochemical composition of Mozzarella and Cheddar cheese ( 2 and 4 months ripened) are given in Table 2.

Table 2. Mean values of physicochemical composition of natural cheeses.

\begin{tabular}{lccc}
\hline Parameters & Mozzarella & \multicolumn{2}{c}{ Cheddar cheese } \\
\cline { 3 - 4 } & cheese & $\begin{array}{c}\text { 2 months } \\
\text { ripened }\end{array}$ & $\begin{array}{c}\text { 4 months } \\
\text { ripened }\end{array}$ \\
\hline Moisture & $46.95 \pm 1.00$ & $35.36 \mathrm{a} \pm 0.47$ & $35.26 \mathrm{~b} \pm 0.20$ \\
$\mathrm{pH}$ & $4.88 \pm 0.01$ & $5.21 \mathrm{a} \pm 0.05$ & $5.0 \mathrm{~b} \pm 0.04$ \\
Acidity & $0.9 \pm 0.2$ & $0.88 \mathrm{~b} \pm 0.005$ & $0.82 \mathrm{a} \pm 0.01$ \\
Protein & $25.36 \pm 1.18$ & $28.23 \pm 0.20$ & $28.20 \pm 0.10$ \\
Fat & $20.01 \pm 1.73$ & $22.33 \pm 1.15$ & $22 \pm 1.00$ \\
Total Ca g/100g & $0.7 \pm 0.005$ & $0.82 \pm 0.03$ & $0.84 \pm 0.02$ \\
\hline
\end{tabular}

Physicochemical composition of Processed pizza cheeses $(\boldsymbol{P P C})$ : Mean squares for physicochemical composition of PPC are depicted in Table 3. The results demonstrated that blending significantly $(\mathrm{P}<0.05)$ changes physicochemical parameters (moisture, $\mathrm{pH}$, acidity, protein, fat and total calcium) of PPC. Moisture, $\mathrm{pH}$ and acidity of PPC significantly $(\mathrm{P}<0.05)$ affected by the ripening months of Cheddar cheese while protein, fat and total calcium content is not affected by the ripening months of Cheddar cheese. Level of cheeses (Mozzarella and Cheddar) also have significant $(\mathrm{P}<0.05)$ effect on the physicochemical composition of PPC however, interaction of ripening months of Cheddar cheese $\times$ level of cheeses has non-significant $(\mathrm{P}>0.05)$ on physicochemical parameters of PPC.

Mean values for moisture content of PPC are given in Table 4. The results revealed that control pizza cheese $(100 \%$ 
Table 3. Mean squares of physicochemical composition of Processed pizza cheese.

\begin{tabular}{llclllll}
\hline Sources of variation & $\mathbf{d f}$ & Moisture & $\mathbf{p H}$ & Acidity & Protein & Fat & Total calcium \\
\hline Blending & 6 & $13.4696^{*}$ & $0.266^{* *}$ & $0.001727^{* *}$ & $1.95289^{*}$ & $4.9035^{*}$ & $0.006442^{* *}$ \\
Control VS others & 1 & $0.3779^{\mathrm{NS}}$ & $0.0224^{\mathrm{NS}}$ & $0.004000^{* *}$ & $4.66331^{*}$ & $0.7685^{\mathrm{NS}}$ & $0.009257^{* *}$ \\
Months (M) & 1 & $2.6450^{*}$ & $0.0512^{*}$ & $0.002938^{*}$ & $0.03380^{\mathrm{NS}}$ & $0.0018^{\mathrm{NS}}$ & $0.001800^{\mathrm{NS}}$ \\
Levels (L) & 2 & $38.8588^{*}$ & $0.0392^{*}$ & $0.001672^{* *}$ & $3.45515^{*}$ & $14.3223^{*}$ & $0.013650^{*}$ \\
$\mathrm{M} \times \mathrm{L}$ & 2 & $0.387^{\mathrm{NS}}$ & $0.0038^{\mathrm{NS}}$ & $0.000038^{\mathrm{NS}}$ & $0.05495^{\mathrm{NS}}$ & $0.0031^{\mathrm{NS}}$ & $0.000150^{\mathrm{NS}}$ \\
Error & 14 & 0.5411 & 0.0077 & 0.000238 & 0.62604 & 0.4861 & 0.000782 \\
\hline
\end{tabular}

NS = Non-significant $(\mathrm{P}>0.05) ; *=$ Significant $(\mathrm{P}<0.05) ; * *=$ Highly significant $(\mathrm{P}<0.01)$

Table 4. Mean values $(n=3)$ of the physicochemical composition of Processed pizza cheese samples.

\begin{tabular}{lccccccc}
\hline \multicolumn{7}{c}{ Processed pizza cheese } \\
\cline { 2 - 8 } & PPC $_{\mathbf{0}}$ & $\mathbf{P P C}_{\mathbf{1}}$ & $\mathbf{P P C}_{\mathbf{2}}$ & $\mathbf{P P C}_{\mathbf{3}}$ & $\mathbf{P P C}_{\mathbf{4}}$ & $\mathbf{P P C}_{\mathbf{5}}$ & PPC $_{\mathbf{6}}$ \\
\hline Moisture & $51.90 \pm 0.58 \mathrm{a}$ & $49.75 \pm 0.37 \mathrm{~b}$ & $46.15 \pm 0.06 \mathrm{~b}$ & $44.95 \pm 0.07 \mathrm{bc}$ & $49.05 \pm 0.30 \mathrm{~b}$ & $45.50 \pm 0.21 \mathrm{bc}$ & $44.00 \pm 0.18 \mathrm{c}$ \\
pH & $4.89 \pm 0.06 \mathrm{~b}$ & $4.88 \pm 0.06 \mathrm{~b}$ & $4.92 \pm 0.05 \mathrm{~b}$ & $4.99 \pm 0.03 \mathrm{~b}$ & $4.94 \pm 0.04 \mathrm{~b}$ & $5.02 \pm 0.03 \mathrm{ab}$ & $5.15 \pm 0.04 \mathrm{a}$ \\
Acidity & $0.92 \pm 0.01 \mathrm{a}$ & $0.89 \pm 0.02 \mathrm{bcd}$ & $0.87 \pm 0.09 \mathrm{de}$ & $0.85 \pm 0.08 \mathrm{e}$ & $0.91 \pm 0.09 \mathrm{ab}$ & $0.90 \pm 0.01 \mathrm{abc}$ & $0.88 \pm 0.08 \mathrm{cde}$ \\
Protein & $25.37 \pm 0.68 \mathrm{~b}$ & $26.07 \pm 0.48 \mathrm{~b}$ & $26.70 \pm 0.46 \mathrm{ab}$ & $27.51 \pm 0.42 \mathrm{a}$ & $26.04 \pm 0.28 \mathrm{~b}$ & $26.40 \pm 0.29 \mathrm{ab}$ & $27.58 \pm 0.26 \mathrm{a}$ \\
Fat & $18.23 \pm 1.00 \mathrm{c}$ & $19.21 \pm 0.66 \mathrm{bc}$ & $19.78 \pm 0.33 \mathrm{~b}$ & $21.29 \pm 0.66 \mathrm{a}$ & $19.20 \pm 0.33 \mathrm{c}$ & $19.72 \pm 0.88 \mathrm{~b}$ & $21.32 \pm 0.88 \mathrm{a}$ \\
Total Ca & $0.71 \pm 0.09 \mathrm{~d}$ & $0.73 \pm 0.01 \mathrm{~d}$ & $0.78 \pm 0.09 \mathrm{bc}$ & $0.83 \pm 0.02 \mathrm{a}$ & $0.72 \pm 0.02 \mathrm{~d}$ & $0.75 \pm 0.01 \mathrm{~cd}$ & $0.81 \pm 0.01 \mathrm{ab}$ \\
\hline
\end{tabular}

Means sharing similar letters in a column are statistically non-significant $(\mathrm{P}>0.05)$

Mozzarella cheese) has higher moisture content than all other blends. This could be due to impact of moisture differences of natural Mozzarella and Cheddar cheeses as indicated in Table 2. The higher level of moisture in Processed pizza cheeses with high percentage of Mozzarella cheese might be due to Streptococcus thermophillis used as starter culture which has the ability to produce EPS that entrap moisture and reduces the whey expulsion in Mozzarella cheese (Petersen et al., 2000). Higher moisture content in Processed pizza cheese with greater Mozzarella cheese in the present investigation is perhaps a consequence of lower level of calcium in Mozzarella cheese that results in increased casein hydration (Keller et al., 1974). The reduction of moisture in Processed pizza cheeses with ripening and increasing level of Cheddar cheese could be a result of change of physical state of water in cheese, as during ripening the water gets chemically bound which reduce the moisture content in ripened Cheddar cheese. Mean values for $\mathrm{pH}$ of PPC are expressed in Table 4. The highest $\mathrm{pH}$ (5.15) was found in $\mathrm{PPC}_{6}$ while $\mathrm{PPC}_{1}$ exhibited lowest $\mathrm{pH}$ (4.88). The results also illustrated that increasing level of Cheddar cheese increases the $\mathrm{pH}$ of PPC. Moreover, PPC that was prepared with the addition of four months ripened Cheddar cheese has slightly higher $\mathrm{pH}$ as compared to PPC that was prepared with the amalgamation of two months ripened Cheddar cheese. In PPC minor differences in $\mathrm{pH}$ values might be attributed to the fact that $\mathrm{pH}$ of fresh Mozzarella and Cheddar ( 2 and 4 months ripened) used in the pizza cheese was different (Table 2). In similar study conducted by Kaminarides et al. (2007), the $\mathrm{pH}$ of Processed cheese blends prepared by mixing of Halloumi and Kopanisti cheeses and strained yoghurt were detected dissimilar due to $\mathrm{pH}$ difference of initial products used in the combinations.
The increase in $\mathrm{pH}$ with increased level of Cheddar cheese was owing to higher $\mathrm{pH}$ for both two and four months ripened Cheddar cheese. The higher $\mathrm{pH}$ of Cheddar cheese might be due to higher milling $\mathrm{pH}$ (5.3) while in case of Mozzarella cheese milling was carried out at lower $\mathrm{pH}$ (4.88).In previous studies milling $\mathrm{pH}$ of Mozzarella and Cheddar cheese were found in the range of 5.2 to 5.4 with different processing conditions (Yun et al., 1993; Shakeel-Ur-Rehman et al., 2003; Hassan et al., 2004). In the present study milling pH of the Mozzarella cheese was 4.9 because at this $\mathrm{pH}$ the buffalo milk curd exhibited more stretch properties. This increase in $\mathrm{pH}$ of PPC due to increase of more ripened Cheddar cheese perhaps associated with the slow increase of hydration of para-casein and formation of various protein residues in Cheddar cheese during ripening. These breakdown products e.g. carboxyl groups of glutamatic and aspartic acids have ability to attach with $\mathrm{H}+$ during storage and thus reducing the hydrogen ion concentration of the Cheddar cheese that subsequently increase pH of PPC (Guo et al., 1997; Sheehan et al., 2004).

Table 4 shows the mean values for acidity of PPC. It was obvious from the results that the acidity of control pizza cheese was highest from all other amalgams. It possessed greater acidity might be due to Mozzarella cheese in which $\mathrm{pH}$ decreased to 4.88 during cheddaring and more lactose is converted into lactic acid. In present experiment as the level of SRCC increased the acidity decreased. It might be due to higher (5.3) milling pH of Cheddar cheese than Mozzarella cheese (4.88). Moreover, acidity of PPC with four months SRCC were greater than PPC with two months SRCC. It could be due to greater activity of culture that converts more sugars and residual lactose in to lactic acid and other acids. 
Amarita et al., (2001) showed similar results that the acidity increased as the sugars converted into acids. Furthermore, during ripening the acidity was further increased due to biochemical changes like proteolysis, lipolysis and conversion of residual lactose to lactate and citrate (McSweeney, 2004).

The mean values for protein of PPC are demonstrated in Table 4. It was indicated that control pizza cheese has lowest protein content as compared to other cheese blends. Similarly the PPC with higher levels of Mozzarella cheese had less protein contents and PPC with higher levels of SRCC showed greater protein content. The protein varied in cheese blends might be due to Mozzarella and Cheddar cheese protein difference. This variation might be due to difference in cheese making ingredients and conditions in both types of cheeses. In Mozzarella cheese thermophillic cultures (Streptococcus Thermophillus and Lactobacillus Bulgaricus) were used with more proteolytic activity and caused a decrease in protein in Mozzarella cheese due to loss of protein in whey. In case of Cheddar cheese protein recovery was more due to less proteolytic activity of mesophillic cultures (LactococcusLactis sb. Lactis; LactococcusLactis sb. Cremoris) (Najafi et al., 2008).

The reduction of protein content in Mozzarella cheese might also be due to difference of gelation temperature in both cheeses. In case of Cheddar cheese gelation was carried out at $27^{\circ} \mathrm{C}$ while in Mozzarella cheese curd was set at $37^{\circ} \mathrm{C}$. In both type of cheeses chymosin was used which is very sensitive to temperature and its proteolytic activity increased due to higher temperature therefore the protein content of Mozzarella decreased due to more loss of protein in whey. The results of the present study correlated with the finding of Castillo et al. (2006) who reported that excess proteolysis in curd supported the weakening of protein network. This network rearranged with more shrinkage but synersis increased the loss of protein and fat (Hussain et al., 2012).

Table 4 demonstrates the mean values for fat content of PPC. It is indicated from the results that control pizza cheese has less fat content as compared to other PPC. It is also obvious from the results that in PPC as the concentration of SRCC increased the fat content increased respective to the levels of Cheddar used in the formulation. The greater value of fat content with higher level of Cheddar cheese might be due to greater fat content of Cheddar cheese (Table 2). Although the milk was standardized at same fat level but high level in Mozzarella cheese could be due to greater moisture retention in Mozzarella cheese. While in case of Cheddar cheese pressing decreased moisture contents therefore the fat content on dry matter basis increased.By num and Olson (1982) observed that in Cheddar cheese firmness leads to reduction of fat and casein losses therefore the fat recovery in Cheddar cheese is greater than Mozzarella cheese. Furthermore, even though the levels of SRCC were same in two and four months blends but a little reduction of fat content was observed but this difference was non-significant. Wang et al, (2012) observed similar results that there was non-significant variation in the contents of fat for both natural Cheddar cheeses and Processed cheeses during ripening.

Total calcium content of PPC are depicted in Table 4 illustrated that total calcium content in control pizza cheese was less than all other PPC. The less calcium content in control cheese perhaps associated with decreased $\mathrm{pH}$ (4.88) in Mozzarella cheese during cheese manufacturing which solubilize calcium. Total calcium content increased as the level of Cheddar cheese increased. It might be due to less solubilization of colloidal calcium phosphate in Cheddar cheese that results higher level of calcium. Kimura et al. (1992) worked on the effect of calcium on cheese quality and concluded that colloidal calcium phosphate is dissociated from the casein during $\mathrm{pH}$ reduction which reduced the hydrophobic binding sites of submicelles therefore weaken the bond between submicelles and solubilize calcium.

Cheese texture: The mean squares concerning texture profile analysis (TPA) of PPC are depicted in Table 5 which revealed that blending, ripening months of Cheddar cheese and levels of cheeses (Mozzarella and Cheddar) has significant $(\mathrm{P}>0.05)$ effect on hardness, cohesiveness, springiness, gumminess and chewiness of PPC while interaction of ripening months of Cheddar cheese $\times$ levels of cheeses has non-significant effect on the TPA of PPC.

The means for textural parameters (hardness, cohesiveness, springiness, gumminess and chewiness) of PPC are depicted in Figures 1, 2, 3, 4 and 5 which pointed out that blending of Mozzarella and Cheddar cheese considerably changes the TPA of PPC. Control pizza cheese exhibited highest while $\mathrm{PPC}_{6}$ possessed lowest values for textural parameters. It is also indicated that in PPC hardness decreased with increasing concentration and age of Cheddar cheese.

Table 5. Mean squares of texture parameters of Processed pizza cheese.

\begin{tabular}{lcccccc}
\hline Sources of variation & df & Hardness & Cohesiveness & Springiness & Gumminess & Chewiness \\
\hline Blends & 6 & $2611860^{* *}$ & $0.005577^{* *}$ & $0.011444^{* *}$ & $3652587^{* *}$ & $3065726^{* *}$ \\
Control vs others & 1 & $7207838^{* *}$ & $0.0099556^{* *}$ & $0.022400^{* *}$ & $9827977^{* *}$ & $8248660^{* *}$ \\
Months (M) & 1 & $849821^{* *}$ & $0.0072000^{* *}$ & $0.005000^{* *}$ & $1789522^{* *}$ & $1344496^{* *}$ \\
Levels (L) & 2 & $3784254^{* *}$ & $0.0077389^{* *}$ & $0.020217^{* *}$ & $5122837^{* *}$ & $4371184^{* *}$ \\
M $\times \mathrm{L}$ & 2 & $22498^{\mathrm{NS}}$ & $0.0004167^{\mathrm{NS}}$ & $0.000417^{\mathrm{NS}}$ & $26176^{\mathrm{NS}}$ & $29417^{\mathrm{NS}}$ \\
Error & 14 & 15465 & 0.0007000 & 0.000514 & 16090 & 14484 \\
\hline
\end{tabular}

$\mathrm{NS}=$ Non-significant $(\mathrm{P}>0.05) ; *=$ Significant $(\mathrm{P}<0.05) ; * *=$ Highly significant $(\mathrm{P}<0.01)$ 
The changes in the texture characteristics of PPC might be attributed due to difference in physico-chemical composition of Cheddar and Mozzarella cheese (Table 2). No doubt, the moisture content of control pizza cheese (100\% Mozzarella cheese) was higher, but it was negatively correlated with the textural attributes of PPC. It could be related to the higher level of intact case in which incorporates higher values of textural attributes to PPC.

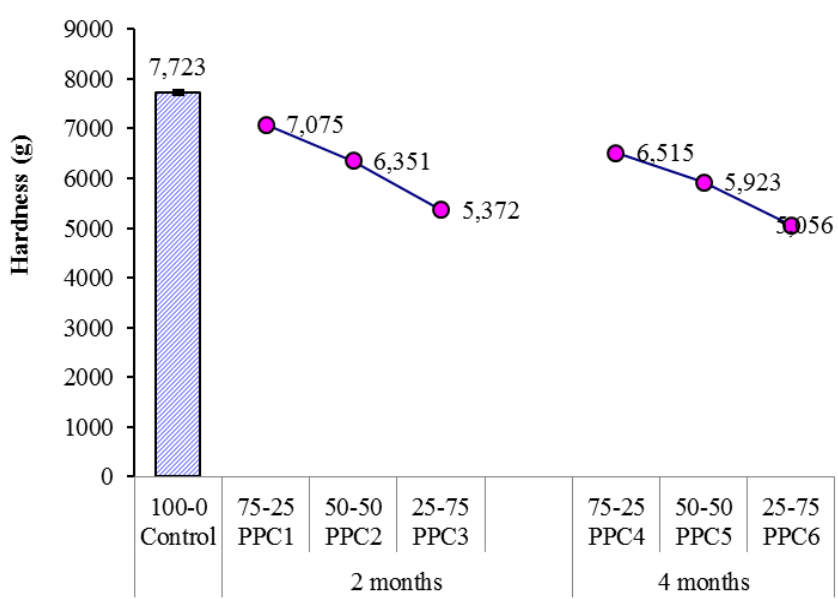

Figure 1. Hardness of Processed pizza cheeses, Control100\% Mozzarella cheese, PPC1, PPC2, PPC3 blends with 75:25, 50:50 and 25:75 Mozzarella: 2 months semi-ripened Cheddar cheese while PPC4, PPC5 and PPC6 blends with 75:25, 50:50 and 25:75 Mozzarella: 4 months semi-ripened Cheddar blends.

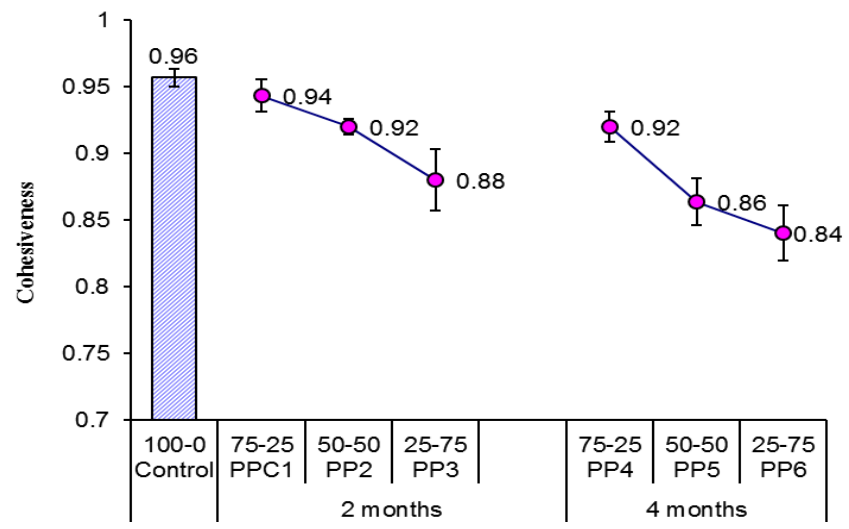

Figure 2. Cohesiveness of Processed pizza cheeses, Control-100\% Mozzarella cheese, PPC1, PPC2, PPC3 blends with 75:25, 50:50 and 25:75 Mozzarella: 2 months semi-ripened Cheddar cheese while PPC4, PPC5 and PPC6 blends with 75:25, 50:50 and 25:75 Mozzarella: 4 months semi-ripened Cheddar blends.

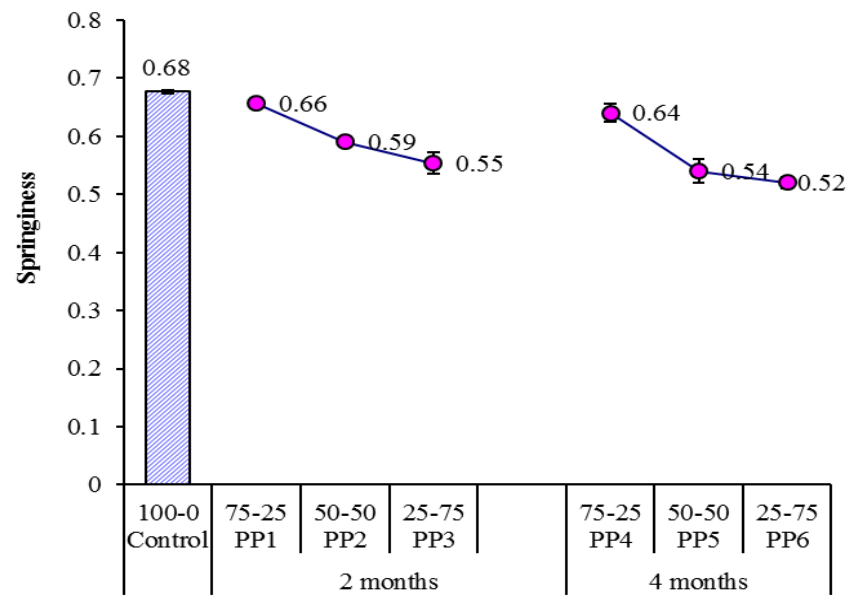

Figure 3. springiness of Processed Pizza cheese, Control$100 \%$ Mozzarella cheese, PPC1, PPC2, PPC3 blends with 75:25, 50:50 and 25:75 Mozzarella: 2 months semi-ripened Cheddar cheese while PPC4, PPC5 and PPC6 blends with 75:25, 50:50 and 25:75 Mozzarella: 4 months semi-ripened Cheddar blends.

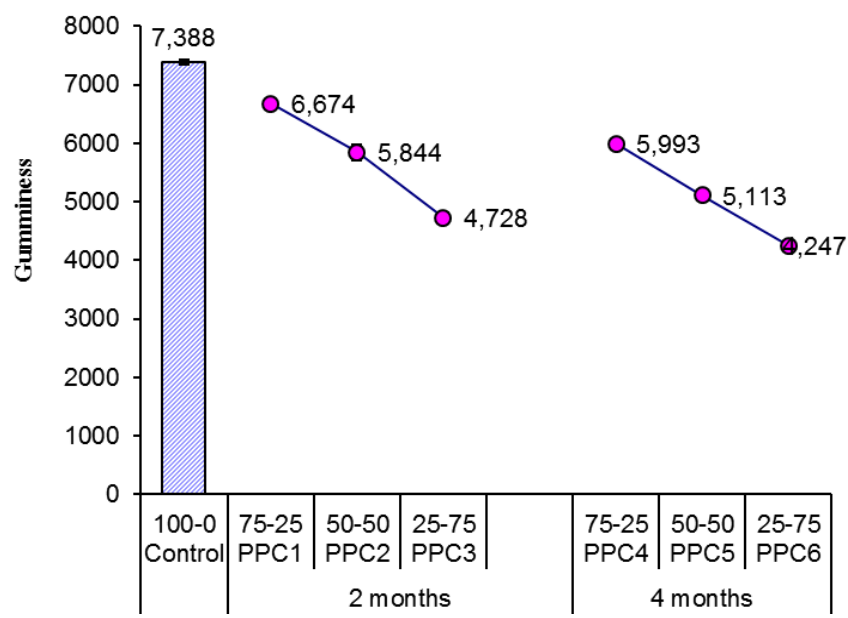

Figure 4. Gumminess of Processed pizza cheeses, Control$100 \%$ Mozzarella cheese, PPC1, PPC2, PPC3 blends with 75:25, 50:50 and 25:75 Mozzarella: 2 months semi-ripened Cheddar cheese while PPC4, PPC5 and PPC6 blends with 75:25, 50:50 and 25:75 Mozzarella: 4 months semi-ripened Cheddar blends.

The higher levels and longer ripening of Cheddar cheese are associated with greater proportion of hydrolytic protein due to formation of more amino acids and peptides during ripening. The interaction between protein networks becomes week and PPC with softer texture are obtained (Sousa and McSweeney 2001); therefore, values for all texture attributes reduced with increased ripened cheese. 


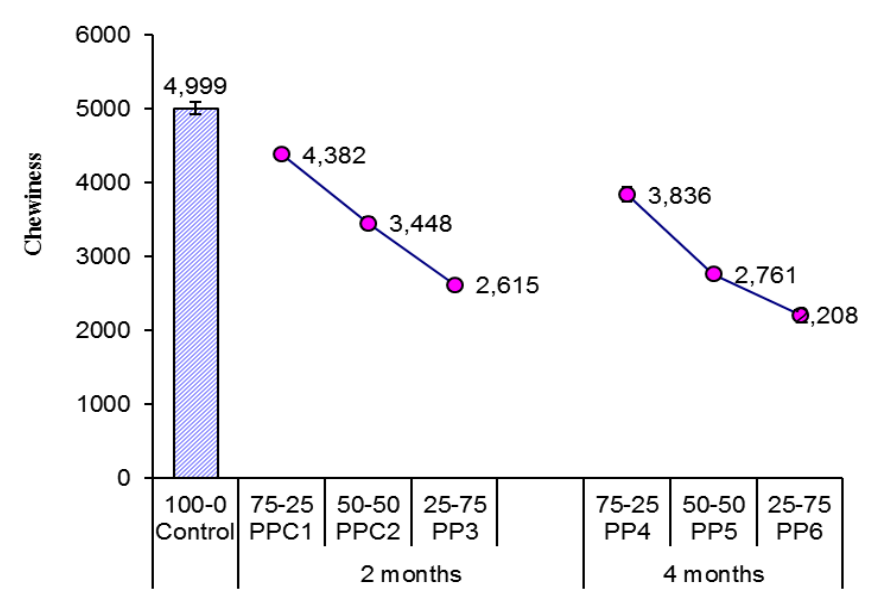

Figure 5. Chewiness of Processed pizza cheese, Control$100 \%$ Mozzarella cheese, PPC1, PPC2, PPC3 blends with 75:25, 50:50 and 25:75 Mozzarella: 2 months semi-ripened Cheddar cheese while PPC4, PPC5 and PPC6 blends with 75:25, 50:50 and 25:75 Mozzarella: 4 months semi-ripened Cheddar blends.

In PPC, changes in TPA might be due to difference of structural components arrangements. The cheeses made with the addition of more percentage of Mozzarella showed less porosity due to strong protein network thereby, have higher value of textural attributes while in Pizza cheese containing ripened Cheddar cheese, the values decreased, which might be due to more structural disintegration and expanded protein network (micrograph not shown here) (Awad et al., 2005; Brickley et al., 2008; Lu et al., 2008; Ong et al., 2012).

$\mathrm{pH}$ is also another important factor that may affect the texture of PPC. It has been observed that as the concentration of Cheddar cheese increased in Pizza cheese blend, the $\mathrm{pH}$ value also increased. Higher $\mathrm{pH}$ produce negative charge on the casein which leads to repulsion forces in casein matrix, that may weakens the protein structure and all the texture attributes (Bunka et al., 2014).

The present investigation showed some conflicting results to that of previous studies. cohesiveness were observed in the range of 0.95-0.84 and it was reduced during ripening but in a study conducted by Hladka et al. (2014) cohesiveness of processed cheese manufactured from Edam cheese at different maturity levels (1,8 and 16 weeks) were in the range of 0.47-0.53. They reported that there was no dependence of maturity level on the cohesiveness level of cheese.

Conclusion: Mozzarella is the most popular cheese used for pizza topping. Although, fresh Mozzarella cheese is preferred but in addition to lack of flavor, it suffers from textural problems such as excessive firmness, rubbery texture, and decreased melting properties. In order to reduce these limitations Mozzarella and semi-ripened Cheddar cheese were processed in different combinations to obtain better foundation properties from Mozzarella while soft and melting characteristics from Cheddar. Mozzarella cheese was milled at $\mathrm{pH} 4.9$ which has greater electrostatic repulsion thereby becomes more hard while Cheddar cheese possessed greater $\mathrm{pH}$ (5.4) with less repulsion forces. The results of chemical composition indicated that protein-protein interactions in Processed pizza cheese were decreased due to less electrostatic repulsion contributed by semi-ripened Cheddar cheese as indicated by microstructure (micrograph is not given here). Moisture retention also increased in blends perhaps due to disintegration of paracaseinate complex and mechanical shear and temperature of processing. Hardness, cohesiveness, springiness, gumminess and chewiness decreased in blends with greater semi-ripened Cheddar cheese due to reducing level of intact casein, more $\alpha$-s1 hydrolysis and casein hydration, less number of cross-linkages induced by Ca.

Acknowledgment: The author acknowledges National Institute of Food Science and Technology for assistance of research work and Higher Education Commission to provide funds.

\section{REFERENCES}

Amarita, F., T. Requena, G. Taborda, L. Amigo and C. Pelaez. 2001. Lactobacillus casei and Lactobacillus plantarum initiate catabolism of methionine by transamination, J. Appl. Microbiol. 90: 971-978.

AOAC. 1990. Official Methods of Analysis. The association of official analytical chemists, $15^{\text {th }}$ Ed. Arlington, USA.

Awad, R.A., L.B. Abdel-Hamid, S.A. El-Shabrawy and R.K. Singh. 2005. Texture and microstructure of block type processed cheese with formulated emulsifying salt mixtures. Lebensm.-Wiss. u.-Technol. 35: 54-61.

Brickley, C.A., S. Govindasamy-Lucey, J.J. Jaegii, M.E. Johnson, P.L.H. McSweeney and J.A. Lucey. 2008. Influence of emulsifying salts on the textural properties of nonfat process cheese made from direct acid cheese bases. J. Dairy Sci. 91: 39-48.

Bunka, F., L. Doudova, E. Weiserova, M. Cernikova, D. Kuchar, S. Slavikova, G. Nagyova, P. Ponizile, T. Gruber and J. Michalek. 2014. The effect of concentration and composition of ternary emulsifying salts on the textural properties of processed cheese spreads. LWT- Food Sci. Technol. 58: 247-255.

Bynum, D.G. and N.F. Olson. 1982. Influence of curd firmness at cutting on cheddar cheese yield and recovery of milk constituents. J. Dairy Sci. 65: 2281-2290.

Castillo, M., J.A. Lucey, T. Wang and F.A. Payne. 2006. Effects of temperature and inoculum concentration on rheological and light scattering properties of milk coagulated by a combination of bacterial fermentation 


\section{Processed pizza cheese with improved functional quality}

and chymosin. Cottage cheese-type gels. Intl. Dairy J. 16: 131-145.

Garimella, P.S.K, A. Pollard and L.E. Metzger. 2006. Effect of formulation and manufacturing parameters on process cheese food functionality-I. trisodium citrate. J. Dairy Sci. 89: 2386-2396.

Guo, M.R., J.K.A. Gilmore and P.S. Kindstedt. 1997. Effect of sodium chloride on the serum phase of Mozzarella cheese. J. Dairy Sci. 80: 3092-3098.

Hassan, A., M.E. Johnson and J.A. Lucey. 2004. Changes in the proportions of soluble calcium and insoluble calcium during the ripening of cheddar cheese. J. Dairy Sci. 87: 854-862.

Hickey, D.K., K.N. Kilcawley, T.P. Beresford, E.M. Sheehan and G.W. Martin. 2007. Starter strain related effects on the biochemical and sensory properties of cheddar cheese. J. Dairy Res. 74: 9-17.

Hladka, K., Z. Randulova, B. Tremlova, P. Ponízil, P. Mancík, M. Cerníkova and F. Bunka. 2014. The effect of cheese maturity on selected properties of processed cheese without traditional emulsifying agents. LWT Food Sci. Technol. 55: 650-656.

Hussain, I., J. Yan, A.S. Grandison and A.E. Bell. 2012. Effects of gelation temperature on mozzarella-type curd made from buffalo and cows' milk: 2. Curd yield, overall quality and casein fractions. Food Chem. 135: 14041410.

International Dairy Federation. 1964. Determination de la teneuren case ine du lait, International Standard FIL-IDF. Lait. 29.

Johnson, M.E. and J.A. Lucey. 2006. Calcium: A key factor in controlling cheese functionality.Aust. J. Dairy Technol.61: 77-83.

Kaminarides, S., P. Stamou and T. Massouras. 2007. Changes of organic acids, volatile aroma compounds and sensory characteristics of Halloumi cheese kept in brine. Food Chem. 100: 219-225.

Kapoor, R., L.E. Metzger, A.C. Biswas and K. Muthukummarappan. 2007. Effect of natural cheese characteristics on process cheese properties. J. Dairy Sci. 90: 1625-163.

Keller, B., N.F. Olson and T. Richardson. 1974. Mineral retention and rheological properties of mozzarella cheese made by direct acidification. J. Dairy Sci. 57: 174-180.

Kimura, T., Y. Sagara, M. Fukushima and S. Taneya. 1992. Effect of $\mathrm{pH}$ on submicroscopic structure of string cheese. Milch-wissenschaft 47: 547-552.

Lee, S.K. and H. Klostermeyer. 2001. The effect of $\mathrm{pH}$ on the rheological properties of reduced-fat model processed cheese spreads. LebensmWiss Technol. 34: 288-292.

Lee, S.K., S. Anema and H. Klostermeyer. 2005. The influence of moisture content on the rheological properties of processed cheese spreads. Intl. J. Food Sci. Technol. 39: 763-71.
Lu, Y., N. Shirashoji and J.A. Lucey. 2008. Effects of pH on the textural properties and meltability of pasteurized process cheese made with different types of emulsifying salts. J. Food Sci. 73: 363-369.

Marshal, R.T. 1992. Standard methods for determination of dairy products. American Punlic Health Association. 16 ${ }^{\text {th }}$ Ed., Washington, D.C.

McSweeney, P.L.H. 2004.Biochemistry of cheese ripening. Intl. J. Dairy Technol. 57: 127-144.

Metzger, L.E., D.M. Barbano, M.A. Rudan and P.S. Kindstedt. 2000. Effect of milk preacidification on low fat mozzarella cheese. I. Composition and yield. J. Dairy Sci. 83: 648-658.

Moynihan, A.C., S. Govindasamy-Lucey, J.J. Jaeggi, M.E. Johnson, J.A. Lucey and P.L.H. McSweeney. 2013. Effect of camel chymosin on the texture, functionality, and sensory properties of low-moisture part-skim mozzarella cheese. J. Dairy Sci.97: 85-96.

Najafi, M.N., A. Koocheki and M. Mahdizadeh. 2008. Studies on the effect of starter culture concentration and rennet $\mathrm{pH}$ on the Iranian brine cheese yield. Amrican- Eurasian J. Agric. Environ Sci. 3: 325-332.

Ong, L., R.R. Dagastine, S.E. Kentish and S.L. Gras. 2012. The effect of $\mathrm{pH}$ at renneting on the microstructure, composition and texture of cheddar cheese. Food Res. Intl. 48: 119-130.

Ong, L., A. Henriksson and N.P. Shah. 2007. Chemical analysis and sensory evaluation of cheddar cheese produced with lactobacillus acidophilus, lactobacillus casei, lactobacillus paracasei or bifidobacterium sp. Intl. Dairy J. 17: 67-78.

Petersen, B.L., R.I. Dave, D.J. McMahon, C.J. Oberg and J.R. Broadbent. 2000. Influence of capsular and ropy exo polysaccharide producing Streptococcus thermophilus on Mozzarella cheese and cheese whey. J. Dairy Sci. 83: 1952-1956.

Shakeel, U.R., N.Y.Farkye and B. Yim. 2003. Use of dry milk protein concentrate in pizza cheese manufactured by culture or direct acidification. J. Dairy Sci.86: 38413848.

Sheehan, J.J. and T.P. Guinee.2004. Effect of $\mathrm{pH}$ and calcium level on the biochemical, textural and functional properties of reduced fat mozzarella cheese. Intl. Dairy J. 14: 161-172.

Shirashoji, N., J.J. Jaeggi and J.A. Lucey. 2006. Effect of trisodium citrate concentration and cooking time on the physicochemical properties of pasteurized process cheese. J. Dairy Sci. 89: 15-28.

Steel, R.G.D., J.H. Torrie and D.A. Dickey. 1997. Principals and Procedures of Statistics: A biometrical approach, 3rd Ed. McGraw Hill Book Co. Inc. New York.

Sousa, M.J. and P.L.H. McSweeney 2001. Studies on the ripening of cooleeney, an Irish farmhouse camembert type cheese. Irish J. Agri. Food Res. 40: 83-95. 
Wang, J. and L. Li. 2012. Comparative study of chemical composition and texture profile analysis between camembert cheese and chinesesufu.Biotechnol. Frontier 1: $1-8$.

Yun, J.J., D.M. Barbano and P.S. Kindstedt. 1993. Mozzarella cheese: Impact of coagulant type on chemical composition and proteolysis. J. Dairy Sci. 76: 3648-3656.
Zisu, B. and N.P. Shah. 2007. Texture characteristics and pizza bake properties of low fat mozzarella cheeses as influenced by pre-acidification with citric acid and use ofencapsulated and ropy exopolysaccharide producing culture. Intl Dairy J. 17: 985-997. 